\title{
KERAGAMAN SERANGGA DAN JENIS PENYAKIT PADA LAHAN TANAMAN BUNCIS (Phaseolus vulgaris L.) DENGAN SISTEM PERTANIAN KONVENSIONAL
}

\author{
Desire Ratnawinda \\ Program Studi Agroteknologi Fakultas Pertanian \\ Universitas Islam Darul 'Ulum Lamongan
}

Desire.ratna@gmail.com

\begin{abstract}
ABSTRAK
Buncis (Phaseolus vulgaris L.) merupakan sejenis polong-polongan yang dapat dimakan buah, biji, dan daunnya dimanfaatkan orang sebagai sayuran. Masalah yang timbul pada budidaya buncis yaitu menurunya kualitas serta produktifitas hasil panen akibat serangan hama dan penyakit. Serangan hama dan penyakit menyebabkan ukuran buncis berbeda-beda serta warnanya yang kurang menarik sehingga harga jual di pasaran pun rendah. Tujuan dari penelitian ini adalah untuk mengetahui jenis hama dan penyakit pada tanaman buncis dan mengetahui pengendalian hama terpadu yang tepat untuk mengendalikan hama dan penyakit. Manfaat yang didapatkan dari penelitian ini adalah untuk mengetahui intensitas serangan hama dan penyakit yang menyerang tanaman buncis dengan cara pengamatan langsung dan menentukan pengelolaan organisme penganggu tanaman yang efektif dan efisien untuk menekan serangan hama dan penyakit. Hasil pengamatan menunjukkan bahwa hama yang menyerang tanaman buncis adalah siput (Achatina fulica), belalang coklat (Phlaeoba fumosa), ulat buah (Helicoverpa armigera), dan kepik emas (Aspidomorpha sanctaecrucis). Penyakit yang ditemukan adalah Penyakit Damping Off (Phytium sp.), karat (Puccinia recondita), Hawar Daun (Xanthomonas campestris). Status serangga hasil pengamatan adalah hama sebesar $42,8 \%$, musuh alami sebesar $57,1 \%$ dan serangga lain sebesar $0 \%$. Rekomendasi pengelolaan lahan tanaman buncis adalah dengan mengatur pola tanam, penggunaan musuh alami untuk mengendalikan populasi hama dan penyakit, serta penggunaan bahan organik sebagai tambahan nutrisi tanah.
\end{abstract}

Kata Kunci : hama tanaman, penyakit tanaman, organisme penganggu tanaman, buncis.

\section{PENDAHULUAN}

Ekosistem pertanian (agroekosistem) memegang faktor kunci dalam pemenuhan kebutuhan pangan suatu bangsa. Keanekaragaman hayati (biodiversiy) yang merupakan semua jenis tanaman, hewan, dan mikroorganisme yang ada dan berinteraksi dalam suatu ekosistem sangat menentukan tingkat produktivitas pertanian. Namun demikian dalam kenyataannya pertanian merupakan penyederhanaan dari keanekaragaman hayati secara alami menjadi tanaman monokultur dalam bentuk yang ekstrim. Hasil akhir pertanian adalah produksi ekosistem buatan yang memerlukan perlakuan oleh pelaku pertanian secara konstan. Berbagai hasil penelitian menunjukkan bahwa perlakuan berupa masukan 
agrokimia (terutama pestisida dan pupuk) telah menimbulkan dampak lingkungan dan sosial yang tidak dikehendaki.

Jasa-jasa ekologis yang diemban oleh keanekaragaman hayati pertanian, diantaranya jasa penyerbukan, jasa penguraian, dan jasa pengendali hayati (predator, parasitoid, dan patogen) untuk mengendalikan hama, sangatlah penting bagi pertanian berkelanjutan. Dengan adanya kemajuan pertanian modern, prinsip ekologi telah diabaikan secara berkesinambungan, akibatnya agroekosistem menjadi tidak stabil. Perusakanperusakan tersebut menimbulkan munculnya hama secara berulang dalam sistem pertanian, salinisasi, erosi tanah, pencemaran air, timbulnya penyakit dan sebagainya (Van Emden \& Dabrowski, 1997). Memburuknya masalah hama ini sangat berhubungan dengan perluasan monokultur dengan mengorbankan keragaman tanaman, yang merupakan komponen bentang alam (landscape) yang penting dalam menyediakan sarana ekologi untuk perlindungan tanaman dan serangga-serangga berguna. Salah satu masalah penting dari sistem pertanian homogen adalah menurunnya ketahanan tanaman terhadap serangga hama, terutama disebabkan oleh penggunaan pestisida yang tidak bijaksana.

Buncis (Phaseolus vulgaris L.) merupakan sejenis polong-polongan yang dapat dimakan. Buah, biji, dan daunnya dimanfaatkan orang sebagai sayuran. Sayuran ini kaya dengan kandungan protein. la dipercaya berasal dari Amerika Tengah dan Amerika Selatan. Buncis adalah sayur yang kaya dengan protein dan vitamin ini membantu menurunkan tekanan darah serta mengawal metabolisme gula dalam darah dan amat sesuai dimakan oleh mereka yang mengidap penyakit diabetes atau hipertensi. Kandungan serat dan enzim yang tinggi dapat membantu penurunan berat badan.

Masalah yang timbul pada budidaya buncis yaitu menurunya kualitas serta produktifitas hasil panen akibat serangan hama dan penyakit. Serangan hama dan penyakit menyebabkan ukuran buncis berbeda-beda serta warnanya yang kurang menarik sehingga harga jual di pasaran pun rendah. Dlaam pelaksanaanya budidaya tanaman buncis sudah baik,sesuai dengan ketentuan-ketentuan budidaya secara intensif, maka produksi perhektar dapat mencapai 150 kwintal polong segar.

Tantangan teknis lain akan muncul karena agribisnis buncis mencakup agroekosistem yang kompleks. Hal ini disebabkan penanamannya bukan hanya seragam dalam areal yang luas, tetapi juga seragam dalam waktu. Penanaman satu jenis tanaman yang terus menerus menjadikan komponen biotik dalam ekosistem alami yang bersangkutan keragamannya sangat rendah. Oleh karena itu, organisme-organisme pengganggu yang hidup pada tanaman cabe akan berkembang secara leluasa dan pada gilirannya dapat terjadi ledakan populasi yang sangat merugikan, dan akan berdampak penggunaan pestisida secara berlebih.

Tujuan dari penelitian ini adalah untuk mengetahui jenis hama dan penyakit pada tanaman buncis, mengetahui kefektifan perangkap hama yang digunakan, dan mengetahui pengendalian hama terpadu yang sudah dilakukan oleh petani. Manfaat yang didapatkan dari penelitian ini adalah dapat mengetahui intensitas serangan hama dan penyakit yang menyerang tanaman buncis dengan cara pengamatan langsung serta memasang beberapa perangkap hama. Selain juga untuk mengetahui jenis pengendalian yang sudah dilakukan oleh petani dalam mennanggulangi serangan hama penyakit.

\section{METODE PENELITIAN}

Pengamatan dilakukan pada lahan tanaman buncis dengan sistem pertanian masih menggunakan pestisida kimia sintetis. Penelitian dilakukan di Desa Kepuh Rajo, Kecamatan Karangploso, Kabupaten Malang pada bulan November hingga Desember 2017. 
Pemasangan perangkap :

a. Sweep net

Ambil serangga menggunakan jaring sweep net dengan teknik yang benar. Gunakan aspirator jika ad serangga kecil di jaring. Masukan serangga yang di dapat kedalam kantong plastik. Kemudian amati.

b. Pitfall

Metode yang digunakan yaitu metode diagonal. Peletakan perangkap pada 2 sisi kiri lahan dan 2 sisi kanan kemudian satu tepat ditengah lahan plot pengamatan. Letakan gelas aqua yang berisi larutan detergen sejajar permukaan tanah.

c. Lighttrap

Lighttrap dipasang malam hari ditengah lahan plot pengamatan. Lampu badai dikaitkan ke ajir menggunakan kawat. Bentuk karton menyerupai corong dan letakan tepat dibawah lampu. Kemudian letakkan ember yang berisi larutan detergen

d. Yellowtrap

Tempelkan yellowtrap melingkari ajir kemudian letakan yellowtrap disi kiri plot lahan sedikit menjorok kedalam (bukan di sisi border).

Pengamatan penyakit dilakukan dengan identifikasi gejala dan tanda pada penyimpangan yang terjadi di tempat observasi.

\section{HASIL DAN PEMBAHASAN}

\section{Klasifikasi Serangga Hama Dan Musuh Alami}

1. Siput ( Achatina fulica)

Klasifikasi :

$\begin{array}{ll}\text { Kerajaan } & \text { : Animalia } \\ \text { Filum } & \text { : Mollusca } \\ \text { Kelas } & \text { : Gastropoda } \\ \text { Superfamili } & \text { : Achatinoidea } \\ \text { Famili } & \text { : Achatinidae } \\ \text { Upafamili } & \text { : Achatininae } \\ \text { Genus } & \text { : Achatina } \\ \text { Upagenus } & \text { : Lissachatina } \\ \text { Spesies } & \text { : A. fulica }\end{array}$

Gejala

Hama tersebut dapat menghabiskan daun hingga yang tersisa tulang daun beserta jalur-jalur kecil mesofilnya sehingga daun menjadi kering kecokelatan. Bila ini dibiarkan, produksi buah bisa berkurang.

Siput juga dapat menyerang tanaman pare. Tanaman terkoyak-koyak dan rusak. Bila tanaman masih kecil, serangan siput bisa mematikan. Bagian tumbuhan yang diserang bekicot berbeda-beda mulai dari bagian kulit batang, daun, bunga, buah, tumbuhan muda, sisa tumbuhan yang telah kering sampai bagian keseluruhan dari tumbuhan tersebut.

Siklus hidup

Siput berkembang biak dengan kawin dan bersifat hemaprodit, tetapi tidak mempu melakukan autofertilisasi. Alat reproduksinya disebut ovotestis, yaitu suatu 
badan penghasil ovum dan sperma. Sperma yang dihasilkan akan diteruskan ke saluran sperma., ditampung dalam kantung sperma dan dikeluarkan melalui alat kawin. Sedangkan sel telur yang dihasilkan akan diteruskan ke saluran telur, reseptakel seminal, dan akhirnya keluar melalui lubang kelamin.

Walaupun Gastropoda merupaka organisme hemaprodit, agar terjadi reproduksi tetap diperlukan dua individu. Reproduksi dimulai ketika dua Gastropoda saling mendekat dan saling memasukkan penis masing-masing ke lubang kelamin pasangannya untuk memindahkan sperma. Setelah itu keduanya berpisah dan masing-masing Gastropoda meletakkan telur yang telah dibuahi dan dilindungi oleh zat gelatin pada tempat yang gelap.

Telur yang dibuahi akan terlindung oleh cangkang kapur, diletakkan di atas bebatuan atau sampah. Karena pengaruh suhu lingkungan, telur akan menetas. Ketika masih berbentuk larva, tubuh Gastropoda bersimetri bilateral, tetapi setelah dewasa tubuhnya mengalami pembengkokan sehingga menjadi tidak simetri (asimetri).

\section{Daur Hidup Siput}

Mengendalikan siput akan sia-sia tanpa mengetahui daur hidup siputnya yang benar, terutama masa kritisnya. Secara ringkas daur hidup siput dapat di bagi menjadi 4 tahap, sebagai berikut:

a. Masa Bertelur

Siput jantan dan betina yang sudah dewasa dan kelaminnya akan saling mencari, dan ketika akan ketemu maka akan terjadi perkawinan. Siput jantan akan membuahi sel-sel telur yang tedapat didalam tubuh induk betina. Kemudian induk betina akan bertelur dan menepatkannya di tepi kolam, tonggak kayu, daun-daunan, atau pempat lainnya.

Telur-telurnya yang berwarna merah muda seperti buah murbei, dan menggumpal. Ketika di keluarkan telur-telur tersebut masih lunak dan bersaput lendir, akan tetapi dalam beberapa waktu kemudian telur-telur tersebut mongering dan mengeras setelah mengeras, telur-telur tersebut merekat erat pada substratnya.

Telur akan menetas dalam jangka waktu satu hingga dua minggu sejak di keluarkan. Ketika menetas anak-anak siput yang masih kecil akan langsung jatuh ke dalam air, pada fase ini sebenarnya kondisi siput dalam keadaan lemah. Selai belum bisa mencari makanan, meraka juga belum dapat berpindah tempat sendiri, dan juga sangat mudah untuk di mangsah oleh binatang yang lain. Akan tetapi yang perlu di ingat, meskipun secara fisik mereka belum bisa berpindah tempat sndiri, justru fase itulah siput bisa menyebar ke berbagai wilayah dengan cepat dalm jumlah yang banyak.

b. Masa Pertumbuhan Awal.

Setelah menetas siput-siput muda akan menyebar terbawa oleh air atau berjalan sendiri. Masa ini adalah masa yang paling sulit untuk mengendalikannya. Meskipun kehadirannya di sawah belum begitu membahayakan, namun wujudnya yang kecil dan sulit di temukan akan menimbulkan bahaya yang besar ketika mereka sudah beranjak dewasa.

Pengendalian pada masa pertumbuhan awal biasanya hanya akan efektif dengan menggunakan bahan kimia, karena dengan cara mekanis terlalu sulit. Tetapi bisa di pasang saringan pada pintu pemasukan untuk menghambat laju penyebarannya. Masa pertumbuhan awal pada umumnya berkisar antara 15-25 hari. 


\section{c. Masa Pertumbuhan Lanjut.}

Masa petumbuhan laju adalah masa tahap berikutnya, yaitu proses pertumbuhan siput dasi muda manjadi dewasa. Pada fase ini serangan siput di sawah sudah cukup meresahkan, kerena selain sangat rakus, dalam waktu yang tidak begitu lama mereka akan melakukan perkawinan.

Pengendalian siput pada masa pertumbuhan lanjut biasanya cukup efektif dengan menggunakan jebakan, atau secara mekanis. Persemian yang dipagar dengan plastic juga mampu menahan mereka untuk tidak mnyusup ke areal pertanian. Pada umumnya masa pertumbuhan lanjut berlangsung dalam waktu 26-59 hari.

Pengendalian

$\checkmark$ Menjaga kebersihan dan sanitasi lingkungan

$\checkmark$ Menggunakan system irigasi yang baik dan memperhatikan system bercocok tanam yang baik

$\checkmark$ Pengendalian mekanik dapat diakukan dengan cara mengambil siput dan mengumpulkannya, selanjutnya melepaskan scangkang dan mematikan untuk digunakan sebagai kripik atau makanan itik

$\checkmark$ Menggunakan air garam (bila diperlukan) karena ini membuat bekicot mati pelan - pelan

$\checkmark$ Menaburkan Metaldelyne dengan bekatul perbandingan 1:20 banyaknya sekitar $40-50 \mathrm{~kg} / \mathrm{ha}$

$\checkmark$

Bagian tanaman yang diserang

Mead (1961) telah menginventarisasi macam - macam tumbuhan termasuk tanaman budidaya yang menjadi makanan bagi bekicot. Bagian tumbuhan yang diserang bekicot berbeda-beda mulai dari bagian kulit batang, daun, bunga, buah, tumbuhan muda, sisa tumbuhan yang telah kering sampai bagian keseluruhan dari tumbuhan tersebut. Macam-macam tumbuhan yang telah diinventarisasi antara lain papaya (Carica papaya), ketimun (Cucumis sativus), kol (Brassica sp), ketela rambat (Ipomoea batatas), balaran (Ipomoea pescapre) dan sebagainya.

\section{Belalang Coklat ( Phlaeoba fumosa)}

$\begin{array}{ll}\text { Kingdom } & \text { : Animalia } \\ \text { Phylum } & \text { : Arthropoda Latreille } \\ \text { Class } & \text { : Insecta } \\ \text { Order } & \text { : Orthoptera } \\ \text { Family } & \text { : Acrididae } \\ \text { Genus } & \text { : Phlaeoba } \\ \text { Species } & \text { : Phlaeoba fumosa }\end{array}$

\section{Gejala}

Belalang coklat biasanya meninggalkan sobekan besar pada daun yang dimulai dari tepi. Sobekan tersebut disebabkan oleh alat mulut dari belalang yang berupa mandibulata. Gejala kerusakan yang ditimbulkan oleh alat mulut ini antara lain sobekan pada daun, seperti yang terjadi pada serangan belalang. 
Siklus hidup

Umumnya belalang ini bertelur pada awal musim kemarau dan akan menetas pada awal musim hujan, yaitu bulan Oktober dan November. Telur menetas sekitar 5 - 7,5 bulan. Sekitar 90 butir telur diletakkan di kantung berwarna coklat yang panjangnya $2-3 \mathrm{~cm}$. Kantung tersebut dimasukkan ke lubang tanah dengan kedalaman $5-8 \mathrm{~cm}$. lubang kemudian diisi dengan massa berbuih yang dapat mengeras. Demikian pula di atas tanah diberi massa berbuih yang dapat mengeras.

Nimfa yang baru saja menetas berwarna kuning kehijauan dengan bercak hitam. Nimfa keluar dari lubang tanah, lalu naik ke pohon. Nimfa memakan daun pohon yang dihinggapinya hingga tinggal kerangka saja. Warna nimfa kemudian akan berubah warna. Umumnya nimfa berwarna kelabu dan kuning. Setelah bersayap, nimfa terbang dan mencari makanan ke tempat lain. Belalang dewasa ini akan melakukan perkawinan di atas pohon. Setelah itu, belalang akan terbang ke tanah untuk mencari tempat bertelur dan berkumpul di tempat terbuka untuk mencari sinar matahari.

Pengendalian

$\checkmark$ Pemberantasan secara mekanis dengan cara telur belalang di dalam tanah dan nimfa yang ada diambil untuk diberikan pada ayam. Jika mungkin, belalang ditangkap dan dimatikan atau diberikan pada ayam atau binatang piaraan lainnya.

$\checkmark$ Pemberantasan secara kimia, yaitu penyemprotan dengan Phoshdrin, Diazinon, Basudin dan Insektisida ini adalah bisa mengakibatkan kematian jika nimfa atau belalang dimakan ternak atau hewan lain sehingga mempengaruhi lingkungan.

$\checkmark$ Penanaman tanaman bunga, seperti turi ( Sesbania gradiflora) tujuannya untuk mengundang kumbang endol. Kumbang dewasa menyukai bunga, sedangkan larvanya akan memakan telur - telur belalang.

$\checkmark$ Penanaman tanaman yang rimbun di tepi tanaman budidaya karena belalang coklat menyukai bertelur di tempat terbuka.

\section{Bagian tanaman yang diserang}

Biasanya termakannya daun yang biasanya dimulai dari bagian tepi daun menuju kedalam. Pada serangan berat dari serangga ini dapat menyebabkan habisnya daun dan menyisakan tulang daun. (Rukmana, 1997)

\section{Ulat buah ( Helicoverpa armigera)}

Klasifikasi

Kingdom

: Animalia

Phylum

: Arthropoda

Class

: Insecta

Order

: Lepidoptera

Family

: Noctuidae

Genus

: Helicoverpa

Species

: H. armigera

Gejala

Gejala yang ditimbulkan adalah daun berlubang - lubang karena ulat memakan pupus dan daun atas. Pada saat memakan pupus kerusakan tidak 
Nampak, tetapi setelah daun membesar, lubang daun terlihat jelas. Sehingga memakan daun, ulat juga menggerek buah dan memakan bijinya ( Subiyakto, 1999 )

Siklus hidup

Larva (ulat) kecil mempunyai warna yang menarik dan berubah sesuai dengan pertumbuhannya. Pertama-tama berwarna putih kekuningan dengan kepala berwarna hitam, kemudian hijau pucat, kemerah-merahan, kekuning-kuningan dan hitam kemerah-merahan. Panjang ulat dapat mencapai $3,45 \mathrm{~cm}$. Kepompong dibentuk di dalam tanah, lama masa kepompong 12-14 hari.

Ngengat menghisap madu dari bunga tanaman. Biasanya ngengat bertelur pada tanaman yang sedang berbunga, misalnya jagung, sorghum, dan tanaman buah polong. Tujuannya pada waktu menetas, larvanya telah mempunyai pakan berupa buah yang baru saja berkembang. Ngengat bisa bertelur sampai 1.000 butir. Telurnya diletakkan satu per satu dalam jumlah yang besar pada bagian atas tanaman inang. Ulat yang baru menetas kemudian turun ke bawah memakan buahnya. Ulat ini bersifat kanibal. Biasanya dalam satu tongkol jjagung jarang terdapat ulat lebih dari satu atau dua. Ulat dewasa turun ke tanah dan berkepompong di dalam tanah. Perkembangan dari telur sampai ngengat lebih kurang 35 hari.

\section{Pengendalian}

$\checkmark$ Lakukan rotasi tanam

$\checkmark$ Hama dapat disemprot dengan insektisida, ex : Cymbush dan Nuvacron

$\checkmark$ Tanaman liar Mimosa invisa ( pis kucing ) yang sering menjadi tanaman inang dibersihkan

$\checkmark$ Ngengat ditangkap dengan perangkap lampu pada waktu malam hari

$\checkmark$ Kumpulkan dan musnahkan buah terserang, pergiliran tanaman dan waktu tanam sanitasi kebun, pencegahan semprotkan PESTONA atau PENTANA ataupun AERO 810 setiap 1-2 minggu sekali

Bagian tanaman yang diserang

Pada buah tomat, ulat ini masuk ke dalam buah dengan cara melubangi buah, setelah itu memakan bagian dalam buah. Kerusakan yang ditimbulkannya pada buah tomat cukup berat, yaitu buah yang terserang akan rusak, lama-lama rontok dan menjadi busuk basah setelah penyakit sekunder ikut masuk dalam buah.

\section{Kepik Emas ( Aspidomorpha sanctaecrucis )}

Klasifikasi

Kingdom : Animalia

Phylum : Arthropoda

Class : : Insecta - insects

Order : Coleoptera

Family : Chrysomelidae

Genus : : Aspidimorpha

Species : Aspidomorpha sanctaecrucis 
Gejala

Terdapat lubang-lubang pada daun serta daun menjadi transparan seperti bekas gerekan.

Siklus hidup

Serangga ini memiliki metamorfosa holometabol dengan panjang siklus 40-85 hari. Telur berbentuk oval, warna kuning kemerahan, berada dalam pembungkus (ootheca) warna kecokelatan. Stadia larva (Lin dan Hsiao, 2005) berlangsung dalam enam instar, masing-masingnya selama 6-14 hari, pupa 10-18 hari, berwarna kekuningan, bagian punggung berbulu halus kehitaman, imago seperti kura - kura, elitra lebih besar warna bening.

\section{KLASIFIKASI PENYAKIT}

1. Penyakit Damping Off

Kingdom : Fungi

Filum : Oomycota

Kelas : Phycomicetes

Famili : Phytiacee

Genus : : Phytium

Spesies : : Phytium sp

Pada umumnya,serangan penyakit ini menimbulkan gejala yakni bagian batang yang terletak di bawah keping biji (hipokotil) berwarna putih pucat karena mengalami kerusakan klorofil. Akibatnya terjadi nekrosa secara cepat, jaringan yang berada di atas tanah menjadi mengkerut dan mengecil sehingga batang tidak kuat lagi menyangga kotiledon dan kemudian tanaman menjadi roboh.Pengendalian terhadap penyakit ini cukup sederhana, yaitu menyiram tanaman dengan air yang bebas penyakit,dan menyemprotkan pestisida organik yang telah disesuaikan dengan kebutuhan.

2. Penyakit Karat

Klasifikasi Penyakit karat

Kingdom :Fungi

Phylum :Basidiomycota

Class :Basidiomycetes

Ordo :Uredinales

Family :Uredinaceae

Genus :Puccinia

Species :Puccinia recondita

Gejala yang timbul akibat serangan penyakit karat ini yakni: pada jaringan daun terdapat bintik-bintik kecil berwarna cokelat baik dipermukaan daun sebelah atas maupun bawah dan biasanya dikelilingi oleh jaringan khlorosis. Pengendalian terhadap penyakit ini yang harus dilakukan sebagai berikut: menanam bibit buncis yang tahan terhadap penyakit karat, yaitu manoa wonder, mencabut dan membakar tanaman yang telah terjangkit, menggunakan pestisida organic. Penyemprotan pestisida organik ini dilakukan bila intensitas serangan mencapai $10 \%$ dengan selang waktu 7 hari. Penyemprotan dengan pestisida organik efektif dan ramah lingkungan. 
3. Penyakit Hawar Daun

Klasifikasi Hawar Daun

$\begin{array}{ll}\text { Phylum } & \text { : Prokaryota } \\ \text { Kelas } & \text { : Schizomycetes } \\ \text { Ordo } & : \text { Pseudomonadales } \\ \text { Famili } & : \text { Pseudomonadaceae } \\ \text { Genus } & : \text { Xanthomonas } \\ \text { Spesies } & : \text { Xanthomonas campestris }\end{array}$

Tanaman buncis yang terserang penyakit ini biasanya akan terlihat bercak kuning di bagian tepi daun, kemudian meluas menuju tulang daun tengah. Daun terlihat layu, kering dan berwarna cokelat kekuningan. Bila serangannya hebat, daun berwarna kuning seluruhnya dan akhirnya rontok. Kemudian gejala tersebut dapat meluas ke batang, sehingga lama-kelamaan tanaman akan mati. Pengendalian yang dapat dilakukan yakni memakai benih yang bebas dari penyakit,dan selalu menjaga kebersihan lahan tanaman dari gulma dengan melakukan penyiangan.

Tabel 1. Tabulasi Data Pengamatan Keragaman Serangga Pada Tanaman Buncis

\begin{tabular}{|c|c|c|c|c|c|c|c|}
\hline \multirow{2}{*}{$\begin{array}{l}\text { Lokasi } \\
\text { pengambilan } \\
\text { sampel }\end{array}$} & \multicolumn{4}{|c|}{$\begin{array}{l}\text { Jumlah individu yang berfungsi } \\
\text { sebagai }\end{array}$} & \multicolumn{3}{|c|}{ Persentase } \\
\hline & Hama & $\begin{array}{l}\text { Musuh } \\
\text { Alami }\end{array}$ & $\begin{array}{l}\text { Serangga } \\
\text { Lain }\end{array}$ & Total & Hama & $\begin{array}{l}\text { Musuh } \\
\text { Alami }\end{array}$ & $\begin{array}{l}\text { Serangga } \\
\text { Lain }\end{array}$ \\
\hline Minggu 1 & 1 & 2 & - & 3 & $33,33 \%$ & $66,66 \%$ & - \\
\hline Minggu 2 & 2 & 3 & - & 6 & $33,33 \%$ & $50 \%$ & - \\
\hline Minggu 3 & 3 & 4 & - & 7 & $42,8 \%$ & $57,1 \%$ & - \\
\hline Total & 6 & 9 & - & 16 & & & - \\
\hline
\end{tabular}

\section{ANALISA DATA PENGAMATAN}

Dari data yang didapatkan pada pengamatan lapang selama 3 minggu, diperoleh beberapa serangga hama dan musuh alami. Pada minggu pertama diperoleh 1 ulat jengkal semu, 1 belalang dan 1 kepik. Pengamatan kedua didapatkan 1 ulat jengkal semu, 1 bekicot, 1 jangkrik dan 1 laba-laba. Sedangkan pada pengamatan ketiga terdapat 3 kumbang kubah spot, 3 semut dan 1 laba-laba. Species yang ditemukan pada lahan pengamatan kebanyakan tergolong pada musuh alami dibandingkan jenis hama.

Dari data diatas paling banyak di peroleh dari perangkap yang diletakan sejajar permukaan tanah (Pitfall) sedangkan data dari perangkap Yellow Trap tidak ada dikarenakan pada pengamatan pertama Yellow Trap hilang sehingga tida ada data yang bisa dimasukan. Begitu juga dengan Light Trap. Data pengamatan dengan menggunakan Light Trap hanya bisa dilakukan 2 kali, untuk pengamatan ketiga tidak ada disebabkan Light Trap hilang. Sedangkan untuk penyakit yang ditemukan disana yaitu penyakit dumping off, karat dan hawar daun.

Species hama dan musuh alami dijumpai pada 3 minggu pengamatan hanya beberapa. Hal ini bisa disebabkan oleh beberapa faktor, diantaranya jarak antara waktu pemasangan perangkap dengan waktu pengambilan data. Semakin lama jarak waktu semakin besar kemungkinan serangga yang masuk perangkap akan hilang. Hal tersebut dikarenakan faktor Iklim, misalnya hujan, dimana jika terdapat hujan yang deras maka serangga yang sudah masuk perangkap bisa ssssssterpantul kembali keluar dari perangkap. Oleh sebab itu faktor lingkungan juga bisa mempengaruhi ada tidaknya hama yang masuk perangkap. Selain itu teknik peletakan perangkap yang tidak benar juga mempengaruhi. 


\section{PENGAMBILAN KEPUTUSAN}

Pengambilan keputusan dilakukan berdasarkan analisis agroekosistem untuk mengambil tindakan lanjutan tanaman yang akan dibudidayakan. Ekosistem pertanian (agroekosistem) memegang faktor kunci dalam pemenuhan kebutuhan pangan. Keanekaragaman hayati (biodiversiy) yang merupakan semua jenis tanaman, hewan, dan mikroorganisme yang ada dan berinteraksi dalam suatu ekosistem sangat menentukan tingkat produktivitas pertanian. Faktor-faktor penyebab rentannya suatu agroekosistem terhadap eksplosi hama dapat diatasi dengan melakukan pengelolaan agroekosistem agar menjadi lebih tahan terhadap eksplosi hama. Tujuan dari pengelolaan agroekosistem adalah menciptakan keseimbangan dalam lingkungan, hasil yang berkelanjutan, kesuburan tanah yang dikelola secara biologis dan pengaturan populasi hama melalui keragaman hayati serta penggunaan input yang rendah (Altieri, 1994).

Pada lahan pengamatan yang dipilih, sebenarnya telah menunjukkan sistem agroekosistem, namun masih belum sempurna. Tingkat OPT yang menyerang tidak terlalu signifikan banyak. Berdasarkan hasil wawacara pun sangat jarang dilakukan pengendalian OPT secara khusus dan cenderung membiarkannya alami. Hal ini diasumsikan terjadi karena biodiversitas tanaman cukup beragam. Begitu banyak tanaman musiman yang dibudiayakan. Selain itu, orientasi penanaman bukan untukmencari keuntungan sebesarbesarnya, tetapi hanya untuk mencukupi kebutuhan sehari-hari saja.

Sebenarnya dalam pengelolaan agroekosistem yang berorientasi pada lingkungan dan produksi membutuhkan perencanaan khusus. Pengelolaan agroekosistem untuk mendapatkan produksi yang berkelanjutan dan sesedikit mungkin berdampak negatif terhadap lingkungan dan sosial, serta input rendah dimungkinkan dengan menerapkan prinsip-prinsip ekologi sebagai berikut (Reijntes et al., 1992):

1 Meningkatkan daur ulang dan optimalisasi ketersediaan dan keseimbangan alur hara. Prinsip ini dapat dilakukan dengan melakukan rotasi dengan tanaman-tanaman pupuk hijau.

2 Memantapkan kondisi tanah untuk pertumbuhan tanaman dengan mengelola bahan organik dan meningkatkan biota tanah. Pemberian biomassa pada lahan akan menambah bahan organik yang selanjutnya akan meningkatkan biota tanah yang berguna dalam peningkatan kesuburan tanah.

3 Meminimalkan kehilangan karena keterbatasan ketersediaan air melalui pengelolaan air. Air dibutuhkan tanaman untuk dapat berproduksi optimal, sehingga ketersediaannya pada waktu dan jumlah yang cukup, sangat berpengaruh terhadap produktivitas lahan. Pengelolaan air dapat dilakukan dengan teknik-teknik pengawetan air tanah.

4 Meningkatkan keragaman spesies dan genetik dalam agroekosistem, sehingga terdapat interaksi alami yang menguntungkan dan sinergi dari komponen-komponen agroekosistem melalui keragaman hayati.

Kemampuan tanaman untuk bertahan atau toleran terhadap serangga hama atau patogen berhubungan erat dengan properti fisik, kimia dan biologi tanah yang optimal. Tanah dengan kandungan bahan organik tinggi dan aktivitas biologi yang tinggi biasanya menunjukkan adanya kesuburan yang tinggi dan adanya jaringjaring makanan (food web) serta mikroorganisme yang kompleks, sehingga mencegah terjadinya infeksi patogen. Pada lahan yang diamati.

Dalam program pengendalian hama, penambahan keragaman vegetasi bukan merupakan suatu strategi pengendalian yang dapat berdiri sendiri (standalone tactic) dalam 
menyelesaikan masalah hama yang ada. Teknik-teknik pengendalian hama yang penekanannya adalah pengendalian ramah lingkungan dengan pemanfaatan sumberdaya alam yang telah ada untuk menuju sistem pertanian yang berkelanjutan, perlu dikembangkan. Teknik-teknik tersebut difokuskan pada optimalisasi peran musuh alami sebagai faktor mortalitas biotik bagi serangga hama atau sebagai penghambat perkembangan patogen penyakit (Nurindah. 2006). Salah satu musuh alami yang dapat menekan serangga penyakit adalah dari golongan patogen cendawan. Penyakit rebah semai (dumping off) dapat ditekan dengan cendawan mikoriza. Aplikasi mikoriza mampu menekan serangan penyakit rebah semai pada tanaman kedelai (Sclerotium.rolfsii) mencapai 30,80\% dibandingkan dengan perlakuan control (tanpa pemberian mikoriza) (Istiqomah et al., 2014).

Dengan mempertimbangkan beberapa hal di atas, maka rekomendasi tanaman yang dapat dibudidayakan dibagi menjadi 2 katagori :

1. Tanaman musiman dengan tinggi mencapai seperempat sampai setengah tinggi dari tanaman tahunan dan canopy yang tidak terlalu rapat. Misalnya jagung.

2. Tanaman dengan tinggi lebih rendah daripada tanaman point 1. Misalnya sawi, bayam dll.

3. Pengelolaan OPT dengan sistem pertanian berkelanjutan menggunakan musuh alami dari jenis predator, parasit, dan patogen.

\section{KESIMPULAN}

Perlu adanya tindakan pengelolaan terhadap keragaman biodiversitas, salah satu upaya dalam mempertahankan agroekosistem pada lahan buncis. Hama yang banyak menyerang adalah belalang dan penyakit yang paling dikhawatirkan adalah penyakit hawar daun. Pengambilan keputusan agroekosistem dengan tetap mempertahankan biodiversitas tanaman untuk menjaga keseimbangan hama, musih alami dan serangga lain, perlu dilakukan penambahan jenis tanaman menajaga keragaman tinggi tanaman sehingga terjadi persebaran cahaya dan keseimbangan lingkungan. Pengelolaan OPT dengan sistem pertanian berkelanjutan menggunakan musuh alami dari jenis predator, parasit, dan patogen

\section{DAFTAR PUSTAKA}

Anonymous. 2011.http://id.wikipedia.org/wiki/Laba-laba. Diakses pada tanggal 20 Desember 2011.

Anonymous. 2011 http://www.penyuluhpertanian.com/pengendalian-penyakit-layu-padatanaman-cabe Diakses pada tanggal 28 November 2011.

Altieri, M. A. 1994. Biodiversity and Pest Management in Agroecosystems. Haworth Press, New York.

Anonymous. 2011 http://ediskoe.blogspot.com/2008/02/jenis-penyakit-di-paprika-layubakteri.html Diakses pada tanggal 28 November 2011.

Anonymous. 2011 http://life-in-the-backyard.blogspot.com/2011/03/tortoise-beetleaspidomorpha.html Diakses pada tanggal 28 November 2011.

Anonymous. 2011.http://www.gudangmateri.com/2011/04/jenis-ulat-yang-menyerangkawasan.html. Diakses pada tanggal 20 Desember 2011.

Anonymous. 2011.http://petanimora.blogspot.com/2011/05/laporan-dpt-sub-penyakit-karatdaun_20.html. Di akses pada tanggal 20 Desember 2011. 
Bobby.2009. http://petaniberdasicom.blogspot.com/2010/06/hama-dan-penyakit-padatanaman-buncis.html. Diakses pada tanggal 20 Desember 2011.

Istiqomah, I., Sastrahidayat, I.R., Muhibuddin, A., 2014. PENGARUH PENGGUNAAN INANG PERANTARA PADI GOGO TERHADAP POPULASI MIKORIZA DAN INTENSITAS SERANGAN PENYAKIT REBAH SEMAI (Sclerotium rolfsii) PADA KEDELAI (Glycine max L.). J. Hama dan Penyakit Tumbuh. 2, pp-54.

Reijntes, C., Haverkort, B. dan Water-Bayer, A. 1992. Farming for the Future, Macmillan, London. 